\title{
A quantitative analysis of farmland and households' livelihood in rural Vietnam
}

\author{
Duong Huy Phan ${ }^{1}$, Tuyen Quang Tran ${ }^{* 1}$, Anh Phan ${ }^{2}$, Lam Xuan Hoang ${ }^{3}$ \\ ${ }^{1}$ Vietnam National University, Hanoi, Vietnam \\ ${ }^{2}$ Academy of Banking, Hanoi, Vietnam \\ ${ }^{3}$ Huu Nghi University of Technology and Management, Vietnam
}

Using data from the 2014 Vietnam Household Living Standard Survey, this study employs cluster analysis techniques to provide the first classification of five livelihood strategies pursued by rural households. The methodology also included a comparison between the per capita household income across livelihood strategies using the Bonferroni pairwise tests. The authors found that households with non-farming or wage-earning livelihoods achieved the highest income levels, while those depending on farm-related incomes or a mix of wage-earning and farm-related incomes had the lowest income levels. Furthermore, factors associated with the choice of livelihoods were investigated using a multinomial logit model. The findings reveal that farmland is negatively associated with the choice of high return livelihood strategies. This suggests that access to farmland is not a potential barrier to the pursuit of lucrative strategies. In addition, the education level of household heads proved to have a positive effect on the pursuit of remunerative strategies. The authors also found that households living in communes with minimal infrastructure and non-farming job opportunities have a more significant chance to adopt high-return livelihoods.

Key Words: farmland, cluster analysis, livelihoods, household zelfare, mural Vietnam.

Article Info: Received: October 31, 2018; Revised: April 18, 2019; Accepted: November 2, 2019; Online: November 30, 2019.

\footnotetext{
" Corresponding author

Address: International School (Is-Vnu), Vietnam National University, Building G7, Xuan Thuy Street, No. 144, Cau Giay District, Hanoi, Vietnam

Phone: +84.24.3557.5992 | Email: tuyentq@vnu.edu.vn
}

(C)2019 Human Geographies; The authors 


\section{Introduction}

By 2015, Vietnam had a total agricultural land area of around 6,998,000 hectares and a population of $93,571,567$ people. With less than 0.0748 hectares per capita, Vietnam's arable surface per person is much lower than the average for lowermiddle-income countries $(0.136$ hectares $)$ and the world average of 0.174 hectares according to World Bank data. Fortunately, a combination of land fertility, climate favourable for agriculture, and an abundant labour force helps the country to maintain its national food security while also managing to export a large number of agricultural products, such as rice, rubber, cashews, coffee and pepper. As a result, in rural Vietnam, which accounts for three-quarters of the total and most of the poor segment of the population, agriculture is the main source of livelihood for more than half the total workforce (World Bank, 2011).

Numerous studies have examined the role of arable land in the livelihoods of households in rural Vietnam (Nguyen \& Tran, 2013; Ravallion \& Van de Walle, 2008), Vietnam's peri-urban areas (Tran et al., 2014) and the northwest region of Vietnam (Tran et al., 2015). In general, these studies confirm that farmland helps to improve household income and reduce poverty. While most studies focus on how the availability of farmland affects engagement in non-farming activities and household welfare, very few studies examine whether access to arable land may be a potential barrier to adopting remunerative livelihood strategies in rural Vietnam. This gap in literature motivated the authors to conduct the current study. The research questions were as follows: (1) what livelihood strategies are pursued by rural households, (2) which strategies are lucrative and which are not, and (3) whether access to farmland is a potential barrier to engaging in remunerative strategies or not.

The study has two main merits. Firstly, the use of cluster analysis techniques, based on the identification of components of household income by source, to provide a classification of five livelihood strategies pursued by rural households. This method enabled the authors to identify significantly, and mutually exclusive subgroups of observations from a larger aggregate group (Hair et al., 1998). Secondly, the study offers the first evidence of whether access to farmland affects the choice of high return livelihoods in rural Vietnam.

Bonferroni pairwise tests were used to compare household per capita income across the five livelihood strategies identified. The authors found that livelihood strategies based on non-farming or wage-earning activities are the most remunerative, while those specialising in farming or a mix of farming and wagepaying work have the lowest returns. Interestingly, the findings reveal that farmland is negatively associated with the choice of high return livelihood strategies. This suggests that the absence of access to farmland is not a potential barrier to the pursuit of lucrative strategies. However, the education of household heads has a positive impact on the pursuit of remunerative strategies, implying that better education might shift households away from low-return activities. 


\section{Data and methods}

\section{Data}

The current study uses household data from the 2014 Vietnam Household Living Standard Survey (VHLSS). The VHLSS was conducted by the General Statistics Office of Vietnam (GSO) with technical help from the World Bank. The survey covered around 9,400 households and is representative at the national and regional level. In this study, the authors used data that included 6,571 rural households. Data on households and individuals consist of basic demography, employment, education, health, income sources, economic activities, housing, durable goods, and land. The data were combined with commune data regarding the natural and social characteristics of the communes in which the households were located. The combined data enable the examination of both household and commune-related factors affecting the choice of household livelihoods.

\section{Methods}

Classification of household livelihood strategies is useful for both academic research and policy work (Ellis, 2000) and requires clustering a vector of various income-earning activities (Nielsen et al., 2013). Cluster analysis is a technique used to identify meaningful, mutually exclusive subgroups of observations from a larger aggregate group (Hair et al., 1998). The method has been used in numerous empirical studies on rural household livelihoods (e.g. Ansoms, 2008; Brown et al., 2006; Jansen et al., 2006; Van den Berg, 2010).

The main sources of income have been used as primary input variables for classifying household livelihood strategies in other empirical research (Nielsen et al., 2013). This approach is reasonable because incomes from distinct sources are the result of work time and livelihood assets allocated to various economic activities (Tran et al., 2014). Consequently, the authors used cluster analysis techniques to identify household livelihood strategies, using data about five income sources, as presented in Table 1.

Table 1. The main four income sources

\begin{tabular}{ll}
\hline Income sources & Definitions \\
\hline 1. Farming work & $\begin{array}{l}\text { Income from self-employment in household agriculture, including crop } \\
\text { and livestock production, forestry and other related activities. }\end{array}$ \\
\hline 2. Non-farming work & $\begin{array}{l}\text { Income from self-employment in non-farming activities (agro- } \\
\text { processing, bakeries, repairs, kiosks, transport, distribution, tourism, } \\
\text { small scale manufacturing, construction, mining). }\end{array}$ \\
\hline 3. Wage-paying work & Income from paid jobs in both the private and public sectors. \\
\hline 4. Non-labour income & $\begin{array}{l}\text { Income from remittances, interest, rentals, subsidies, scholarships and } \\
\text { other income. }\end{array}$ \\
\hline
\end{tabular}


Following Punj \& Stewart (1983), the authors employed a hierarchical method, using the Duda-Hart stopping rule to seek the optimal numbers of clusters (Halpin, 2016). The results show that the largest Duda-Hart Je (2)/Je (1) stoppingrule value is 0.8601 , corresponding to the optimal number of five groups. The cluster analysis was then rerun with five groups, using k-mean clustering. The five livelihood strategies and their corresponding household income structures, reported in Figure 1, include (i) farming and wage-paying livelihoods; (ii) nonlabour income livelihoods; (iii) non-farming livelihoods; (iv) farming livelihoods; and (v) wage-paying livelihoods.

Once the sample households were partitioned into five groups of livelihood strategies, the authors used descriptive statistics to provide a detailed picture of household characteristics and economic activities. As household income is often used to measure household economic welfare in economic development (Coudouel et al., 2002; Deaton, 1997). Following Tran et al., (2018), the authors compared per capita income across livelihood strategies, using Bonferroni pairwise test. This employs a smaller comparison wise error rate that accounts for p-values so that the probability of making one or more type 1 errors over all the different tests is smaller than 5\% (Anderson et al., 2016). Per capita income is assumed to reflect the expected result of a selected livelihood strategy. Household choice of livelihood strategies with low expected income or low probability of earning higher income may reflect the fact that these households face constraints limiting their choice of livelihood (Nielsen et al., 2013).

The authors modelled the factors influencing household choice of livelihood strategy using a multinomial logit model (MNL). The MNL model provides a set of equations, each of which shows the effect of explanatory variables on the logodds ratio $\ln \left[\frac{P \mathrm{ij}}{P i k}\right]=x_{i} \beta_{j}$. For each unit change of $x_{i}$, the coefficients $\beta_{j}$ show the change in the log-ratio between the likelihood of choosing livelihood strategy $j$ and the likelihood of choosing livelihood $k$ (Greene, 2003). In this paper, in contrast with other livelihood strategies, the farming work livelihood group constitutes the reference or base group $k$.

Following the micro policy analysis framework for rural livelihoods proposed by Ellis (2000), the authors selected several variables as important factors in the choice of livelihood strategy. These were (i) household size and dependency ratio (calculated by the number of household members under 15 and over 59, divided by the total members aged 15-59), the age and education of the household head, (iii) the size of various land plots and (iv) commune and province dummy variables, which were also included in the model to control for fixed regional effects. Also included in the model are other commune-related factors, such as transport infrastructure access and the availability or development of irrigation facilities, and opportunities for non-farming jobs in the communes. The definition and measurements of included variables are provided in Table 3. 


\section{Results and discussion}

\section{Descriptive statistics on household livelihoods}

Figure 1 and Tables 2 and 3 provide a statistical description of household livelihood strategies. As shown in Figure 1, four livelihoods based on income from labour and one non-labour income livelihood were classified via cluster analysis techniques. The main features of household livelihood strategies according to their household characteristics are presented in Table 2 and Figure 1. It is evident that on average, households with farming livelihoods had more significant areas of annual and perennial croplands compared with other livelihoods. However, the data show that $31 \%$ of the sample had no annual cropland, and about $80 \%$ had no perennial cropland. The household heads of non-farming and wageearning livelihoods had better education than did those specialising in non-labour livelihoods, farming livelihoods and both farming and wage-earning livelihoods.

Figure 1 shows that income from wages and farming account on average, for about $36 \%$ and $35 \%$ respectively of the total household income, while nonfarming and other non-labour incomes contribute about $13 \%$ and $16 \%$ respectively to the total household income. On average, wages and agricultural incomes make up about $47 \%$ and $40 \%$ respectively of the total household income for households choosing farming and wage-earning livelihoods. The average contribution of non-labour income is about $78 \%$, while the average share of agricultural income accounts for about $15 \%$ of total household income among households adopting non-labour livelihoods. Wage income, on average, contributes about $78 \%$ to the total for those having wage-paying livelihoods, whereas the average contribution of non-farming income is estimated at about $82 \%$ of total household income among those whose livelihoods derived from nonfarming work.

Table 2 shows mean livelihood outcomes by livelihood group. It shows that on average, households whose livelihoods derive from wage-paying or non-farming had the highest levels of per capita income and owned durable assets of higher total value compared with other livelihood groups. Table 2 indicates that about one-fifth of households in the farming livelihood strategy group were poor while the corresponding figures for those depending on farm-work and non-farmingwork livelihoods were only $3 \%$ and respectively $2 \%$. Also, the level of income inequality varies significantly across livelihood groups. Specifically, inequality is much higher among those depending on farming and non-labour livelihoods.

Table 4 compares livelihood outcomes across all groups. Bonferroni pairwise tests were conducted in order to rank the outcomes of each livelihood strategy in terms of household income per capita, the value of durable assets and poverty rate. Non-farming livelihoods offer the highest income, while livelihoods specialising in farming and those based on a mix of farming and wage-paying work have the lowest incomes. Table 4 indicates that this group received a monthly per capita income about 1.032 million Vietnamese dongs (VND) higher than the wage-earning livelihood group and about 1.041 million VND higher than the wage-earning and farm-work livelihood group. 


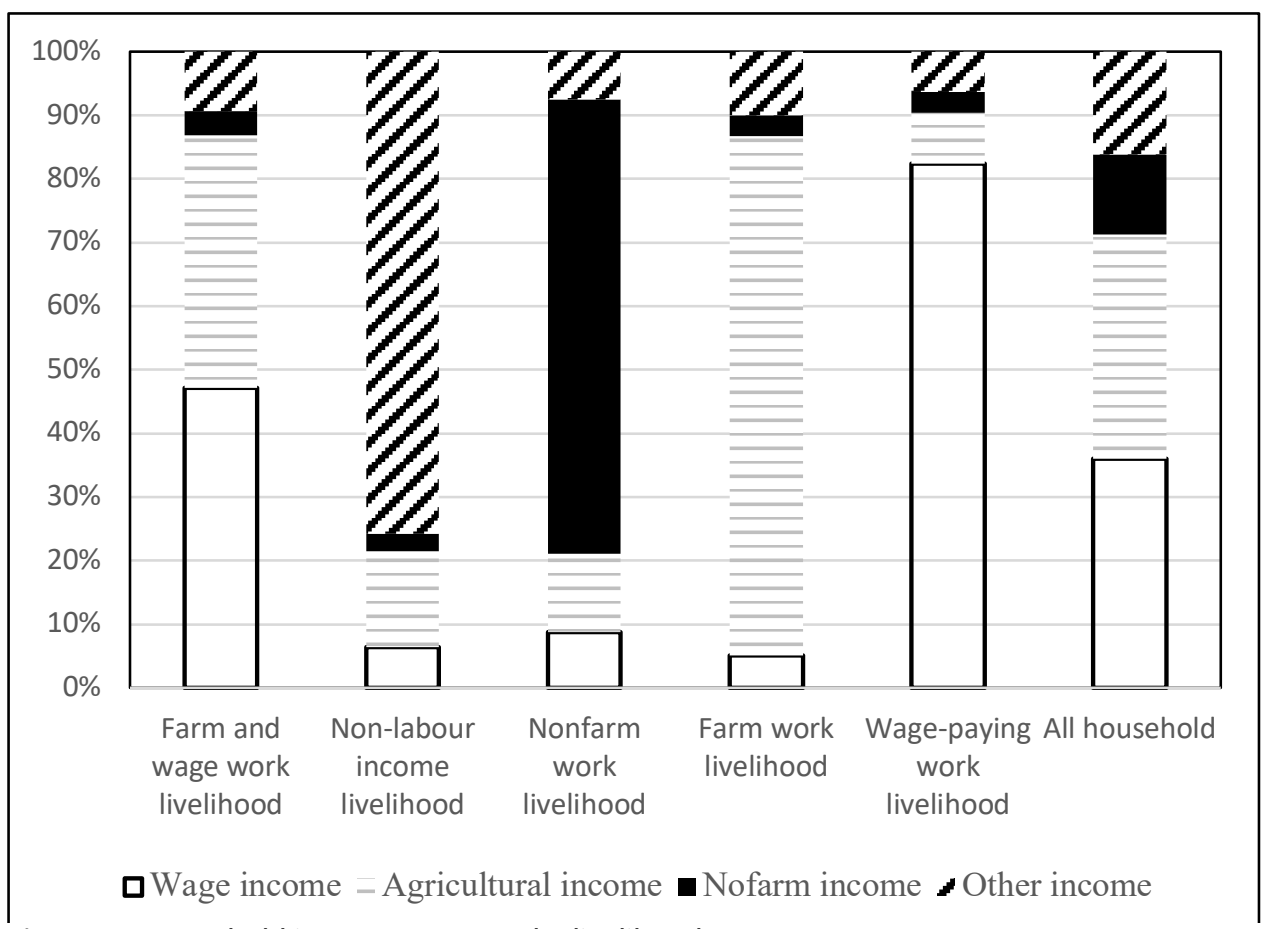

Figure 1. Household income structure by livelihood group/strategy

Source: authors' calculations from using data the VHLSS 2014

Table 2. Livelihood outcomes by strategy group

\begin{tabular}{lcccccc}
$\begin{array}{l}\text { Livelihood } \\
\text { outcomes }\end{array}$ & Farming & $\begin{array}{c}\text { Non- } \\
\text { labour }\end{array}$ & $\begin{array}{c}\text { Wage earnings } \\
\text { \& farming }\end{array}$ & $\begin{array}{c}\text { Wage } \\
\text { earnings }\end{array}$ & $\begin{array}{c}\text { Non } \\
\text { farming- } \\
\text { work }\end{array}$ & $\begin{array}{c}\text { All } \\
\text { households }\end{array}$ \\
\hline $\begin{array}{l}\text { Monthly per capita } \\
\text { income }\end{array}$ & 1,783 & 2,100 & 1,674 & 2,231 & 2,815 & 2,069 \\
\hline SD & $(1,981)$ & $(2,521)$ & $(1,105)$ & $(1,355)$ & $(3,371)$ & $(2,057)$ \\
\hline $\begin{array}{l}\text { Current value of all } \\
\text { durable assets }\end{array}$ & 23,275 & 18,347 & 23,556 & 29,777 & 49,175 & 28,183 \\
\hline SD & $(35,602)$ & $(35,466)$ & $(29,992)$ & $(40,921)$ & $(91,095)$ & $(48,555)$ \\
\hline Poverty rate & 0.21 & 0.12 & 0.10 & 0.03 & 0.02 & 0.10 \\
\hline Inequality (Gini) & 0.47 & 0.45 & 0.33 & 0.30 & 0.36 & 0.39 \\
\hline Observations & 1,738 & 763 & 1,275 & 1,894 & 901 & 6,571 \\
\hline
\end{tabular}

Note: SD: standard deviation

Source: authors' calculations from using data the VHLSS 2014

\section{Comparing household welfare across livelihood strategies}

On average, the income gap between the wage-earning group and the farming group remains at about 447,000 VND and that between the wage-earning group and the wage and farm-work group is about 557,000 VND. However, no income gap was found between the farming group and the farming and wage-earning one. Bonferroni test results in Table 5 also confirm that households with livelihoods deriving from non-farming work owned more high-value durable assets, followed by those depending on wage-earning livelihoods. Notably, Table 
6 shows that the poverty rate is the highest for those whose livelihoods are based on farm work. Overall, the Bonferroni test results show that some livelihoods are superior to others, assuming that households try to maximise their household income.

Table 3. Household and commune characteristics by livelihood strategy

\begin{tabular}{|c|c|c|c|c|c|c|c|c|c|c|c|c|}
\hline \multirow{2}{*}{$\begin{array}{l}\text { Livelihood strategies } \\
\text { Household characteristics }\end{array}$} & \multicolumn{2}{|c|}{$\begin{array}{l}\text { Wages \& } \\
\text { farm-work }\end{array}$} & \multicolumn{2}{|c|}{$\begin{array}{l}\text { Non- } \\
\text { labour }\end{array}$} & \multicolumn{2}{|c|}{$\begin{array}{c}\text { Non- } \\
\text { farming } \\
\text { work }\end{array}$} & \multicolumn{2}{|c|}{$\begin{array}{l}\text { Farm } \\
\text { work }\end{array}$} & \multicolumn{2}{|c|}{$\begin{array}{c}\text { Wage } \\
\text { earnings }\end{array}$} & \multicolumn{2}{|c|}{$\begin{array}{c}\text { All } \\
\text { househo } \\
\text { lds } \\
\end{array}$} \\
\hline & Mean & $\mathrm{SD}$ & Mean & $\mathrm{SD}$ & Mean & $\mathrm{SD}$ & Mean & $\mathrm{SD}$ & Mean & SD & Mean & $\mathrm{SD}$ \\
\hline $\begin{array}{l}\text { Education: years of formal } \\
\text { schooling of household } \\
\text { head }\end{array}$ & 6.93 & 3.91 & 5.83 & 4.04 & 8.09 & 3.36 & 6.09 & 3.68 & 7.96 & 4.38 & 7.03 & 4.04 \\
\hline $\begin{array}{l}\text { Household head's gender: } \\
1=\text { male; } 0=\text { female }\end{array}$ & 0.85 & 0.36 & 0.56 & 0.50 & 0.81 & 0.39 & 0.87 & 0.34 & 0.75 & 0.43 & 0.79 & 0.41 \\
\hline $\begin{array}{l}\text { Age of household head } \\
\text { (years) }\end{array}$ & 49.01 & 12.47 & 63.451 & 15.61 & 48.35 & 12.23 & 48.43 & 13.33 & 49.13 & 14.11 & 50.48 & 14.33 \\
\hline $\begin{array}{l}\text { Marital status of household } \\
\text { head: } 1=\text { married; } 0=\text { not }\end{array}$ & 0.01 & 0.11 & 0.04 & 0.19 & 0.02 & 0.14 & 0.02 & 0.15 & 0.02 & 0.15 & 0.02 & 0.15 \\
\hline $\begin{array}{l}\text { Ethnicity of household } \\
\text { head: } 1=\text { majority; } \\
0=\text { minority }\end{array}$ & 0.71 & 0.46 & 0.91 & 0.29 & 0.95 & 0.23 & 0.62 & 0.49 & 0.89 & 0.31 & 0.79 & 0.41 \\
\hline Dependency ratio $^{\text {a }}$ & 0.32 & 0.25 & 0.61 & 0.39 & 0.32 & 0.25 & 0.35 & 0.28 & 0.34 & 0.26 & 0.37 & 0.30 \\
\hline $\begin{array}{l}\text { Household size: total } \\
\text { number of family members }\end{array}$ & 4.19 & 1.46 & 2.43 & 1.39 & 3.97 & 1.40 & 4.06 & 1.64 & 3.94 & 1.46 & 3.85 & 1.58 \\
\hline Annual cropland: $\mathrm{m}^{2}$ & 4,099 & 5,539 & 2,0264 & 4,871 & 2,315 & 6,927 & 7,288 & 10,471 & 1,295 & 2,574 & $3,660^{\prime}$ & 7,211 \\
\hline Perennial cropland: $\mathrm{m}^{2}$ & 1,191 & 3,740 & 3992 & 2,333 & 775 & 4,370 & 2,886 & 7,947 & 454 & 2,298 & 1,282 & 5,026 \\
\hline $\begin{array}{l}\text { Residential land and } \\
\text { gardens: } \mathrm{m}^{2}\end{array}$ & 595 & 1,059 & 4712 & 2,222 & 380 & 669 & 689 & 1,620 & 392 & 560 & 518 & 1,287 \\
\hline $\begin{array}{l}\text { Household income per } \\
\text { capita }\end{array}$ & 1,674 & 1,105 & 2,1002 & 2,521 & 2,815 & 3,371 & 1,783 & 1,981 & 2,231 & 1,355 & 2,069 & 2,057 \\
\hline \multicolumn{13}{|l|}{ Commune characteristics } \\
\hline $\begin{array}{l}\text { Road access to villages: } \\
1=\text { yes; } 0=\text { no }\end{array}$ & 0.87 & 0.34 & 0.95 & 0.22 & 0.93 & 0.26 & 0.97 & 0.18 & 0.96 & 0.20 & 0.93 & 0.25 \\
\hline $\begin{array}{l}\text { Availability of nonfarm } \\
\text { jobs: } 1=\text { yes; } 0=\text { no }^{\text {b }}\end{array}$ & 0.86 & 0.35 & 0.91 & 0.29 & 0.90 & 0.30 & 0.92 & 0.28 & 0.91 & 0.28 & 0.90 & 0.30 \\
\hline $\begin{array}{l}\text { Availability of irrigation } \\
\text { work: } 1=\text { yes; } 0=\text { no }\end{array}$ & 0.69 & 0.46 & 0.71 & 0.45 & 0.70 & 0.46 & 0.70 & 0.46 & 0.66 & 0.47 & 0.69 & 0.46 \\
\hline $\begin{array}{l}\text { Coastal area: } 1=\text { yes; } \\
0=\text { other }\end{array}$ & 0.05 & 0.23 & 0.07 & 0.26 & 0.03 & 0.18 & 0.06 & 0.24 & 0.05 & 0.22 & 0.06 & 0.23 \\
\hline $\begin{array}{l}\text { Inland delta: } 1=\text { yes; } \\
0=\text { other }\end{array}$ & 0.32 & 0.47 & 0.62 & 0.48 & 0.40 & 0.49 & 0.61 & 0.49 & 0.65 & 0.48 & 0.51 & 0.50 \\
\hline $\begin{array}{l}\text { Hills/midlands: } 1=\text { yes; } \\
0=\text { other }\end{array}$ & 0.03 & 0.16 & 0.03 & 0.18 & 0.05 & 0.22 & 0.06 & 0.23 & 0.05 & 0.21 & 0.04 & 0.20 \\
\hline $\begin{array}{l}\text { Low mountains: } 1=\text { yes; } \\
0=\text { other }\end{array}$ & 0.20 & 0.40 & 0.19 & 0.39 & 0.29 & 0.45 & 0.18 & 0.38 & 0.17 & 0.37 & 0.20 & 0.40 \\
\hline $\begin{array}{l}\text { High mountains: } 1=\text { yes; } \\
0=\text { other }\end{array}$ & 0.39 & 0.49 & 0.08 & 0.27 & 0.23 & 0.42 & 0.09 & 0.29 & 0.09 & 0.29 & 0.19 & 0.39 \\
\hline
\end{tabular}

a This ratio is calculated by the number of members aged under 15 and over 59 , divided by the number of members aged 15-59. ${ }^{b}$ This is question 1 of section 3 in the Commune Questionnaire: "Are there villages with enterprises/firms/factories or traditional occupations within the area that people from this commune can go to and return home within a day?". SD: standard deviation.

Source: authors' calculations from the VHLSS 2014. 
Table 4. Pairwise Comparison of Household Per Capita Income Across Livelihood Groups Using the Bonferroni Method

\begin{tabular}{lcccc}
\hline Row Mean-|Col Mean & $\begin{array}{c}\text { Farm- } \\
\text { work }\end{array}$ & $\begin{array}{c}\text { Non- } \\
\text { labour }\end{array}$ & $\begin{array}{c}\text { Farm and wage- } \\
\text { paying work }\end{array}$ & $\begin{array}{c}\text { Wage paying } \\
\text { work }\end{array}$ \\
\hline Non-labour & 317 & & & \\
\hline Farm and wage- & $(0.00)$ & & & \\
earning work & -109 & -426 & & \\
\hline Wage-earning work & $(1.00)$ & $(0.00)$ & & \\
\cline { 2 - 5 } & $(0.00)$ & $(1.00)$ & $(0.00)$ & 584 \\
\hline Nonfarm work & 1,032 & 715 & 1,141 & $(0.00)$ \\
\cline { 2 - 5 } & $(0.00)$ & $(0.00)$ & $(0.00)$ &
\end{tabular}

Note: Results reported are mean differences in monthly per capita household income; $P$-values are given in parentheses. Unit: 1,000 VND. In 2014, 1 USD was calculated at about 21,000 VND.

Source: Authors' calculation from the 2014 VHLSS.

Table 5. Pairwise Comparison of the Value of Durable Assets Across Livelihood Groups Using the Bonferroni Method

\begin{tabular}{|c|c|c|c|c|}
\hline $\begin{array}{l}\text { Row Mean-|Col } \\
\text { Mean }\end{array}$ & $\begin{array}{l}\text { Farm } \\
\text { work }\end{array}$ & $\begin{array}{l}\text { Non- } \\
\text { labour }\end{array}$ & $\begin{array}{c}\text { Farm and wage } \\
\text { earnings }\end{array}$ & $\begin{array}{c}\text { Wage } \\
\text { earnings }\end{array}$ \\
\hline \multirow[t]{2}{*}{ Non-labour } & $-4,928$ & & & \\
\hline & $(0.17)$ & & & \\
\hline \multirow{2}{*}{$\begin{array}{l}\text { Farm and wage } \\
\text { earnings }\end{array}$} & 281 & 5,209 & & \\
\hline & $(1.00)$ & $(0.17)$ & & \\
\hline \multirow[t]{2}{*}{ Wage earnings } & 6,502 & 11,430 & 6,220 & \\
\hline & $(0.00)$ & $(0.00)$ & $(0.00)$ & \\
\hline \multirow[t]{2}{*}{ Nonfarm work } & 25,899 & 30,828 & 25,618 & 19,397 \\
\hline & $(0.00)$ & $(0.00)$ & $(0.00)$ & $(0.00)$ \\
\hline
\end{tabular}

Note: Results reported are mean differences in the total value of all durable assets per household. $P$ values are given in parentheses. Unit: 1,000 VND. In 2014, the exchange rate was approximately 1 USD to 21,000 VND.

Source: Authors' calculation from the 2014 VHLSS.

Table 6. Pairwise Comparison of the Poverty Rate Across Livelihood Groups Using the Bonferroni Method

\begin{tabular}{lcccc}
\hline $\begin{array}{l}\text { Row Mean-|Col } \\
\text { Mean }\end{array}$ & $\begin{array}{l}\text { Farm } \\
\text { work }\end{array}$ & $\begin{array}{c}\text { Non- } \\
\text { labour }\end{array}$ & $\begin{array}{c}\text { Farm and wage } \\
\text { earnings }\end{array}$ & $\begin{array}{c}\text { Wage } \\
\text { earnings }\end{array}$ \\
\hline Non-labour & -0.09 & & & \\
\hline & $(0.00)$ & & & \\
\hline $\begin{array}{l}\text { Farm and wage } \\
\text { earnings }\end{array}$ & -0.11 & -0.02 & & \\
\hline Wage earnings & $(0.00)$ & $(1.00)$ & & \\
\hline & -0.18 & -0.08 & -0.07 & -0.02 \\
\hline Nonfarm work & $(0.00)$ & $(0.00)$ & $(0.00)$ & $(1.00)$ \\
\hline & -0.19 & -0.10 & -0.08 & $(0.00)$ \\
\hline
\end{tabular}

Note: Results reported are mean differences in the poverty rate; $P$-values are given in parentheses. The poverty rate is calculated using the 2011-2015 poverty margin for rural areas of 605,000 Vietnamese dong (VND) per person per month in 2014 (GSO, 2015).

Source: Authors' calculation from the 2014 VHLSS. 


\section{Factors associated with the choice of livelihood strategy}

Table 7 reports the results from the MNL regression. The relative risk ratios (RRRs) show how many percentages does the likelihood of occurrence of a given outcome is expected to change when there is a unit change in the explanatory variable while all other variables in the model remain constant (Tran et al., 2014). The analysis indicates the effect of explanatory variables on the probability of a household pursuing a given livelihood compared to the probability of choosing a farming livelihood. The results show that the larger the household, the more likely its members are to specialise in non-farming or wage-paying work as their primary source of income. This indicates that farming is a less labour-intensive strategy than others. Possibly, this reflects the fact that a larger family labour pool allows many households to participate intensively in non-farming activities that are more lucrative than farming but also require greater labour input.

Female-led households are more likely than male-led ones to pursue livelihoods based on non-farming work or wage earnings. This suggests that female-led households are more likely to take the initiative to move out of farming activities. The explanation for this may be that the majority of non-farming activities consists of small trades and the provision of local services, which are possibly more suitable for women. This finding is also partially consistent with that of Pham et al. (2010) and Tran et al. (2014), who found that in rural Vietnam, women are more likely than men to engage in non-farming self-employment.

Table 7. Multinomial logit estimates with relative risk ratios for factors associated with livelihood choice

\begin{tabular}{|c|c|c|c|c|}
\hline Explanatory variables & $\begin{array}{c}\text { Farming \& wage } \\
\text { earnings }\end{array}$ & $\begin{array}{c}\text { Non- } \\
\text { labour }\end{array}$ & $\begin{array}{c}\text { Non- } \\
\text { farming }\end{array}$ & $\begin{array}{c}\text { Wage } \\
\text { earnings }\end{array}$ \\
\hline \multicolumn{5}{|l|}{ Household-level factors } \\
\hline \multirow[t]{2}{*}{ Education } & $1.06 * * *$ & $1.05 * * *$ & $1.14 * * *$ & $1.13 * * *$ \\
\hline & $(0.017)$ & $(0.013)$ & $(0.015)$ & $(0.016)$ \\
\hline \multirow[t]{2}{*}{ Gender } & $0.43 * * *$ & $0.76^{* *}$ & $0.46 * * *$ & $0.60 * * *$ \\
\hline & $(0.061)$ & $(0.091)$ & $(0.055)$ & $(0.085)$ \\
\hline \multirow[t]{2}{*}{ Age } & $1.03^{* * *}$ & 1.00 & 1.00 & 0.99 \\
\hline & $(0.005)$ & $(0.004)$ & $(0.004)$ & $(0.004)$ \\
\hline \multirow[t]{2}{*}{ Marital status } & 0.62 & 0.62 & 0.66 & 0.56 \\
\hline & $(0.217)$ & $(0.202)$ & $(0.194)$ & $(0.199)$ \\
\hline \multirow[t]{2}{*}{ Ethnicity } & 1.17 & 0.96 & 1.13 & $4.11 * * *$ \\
\hline & $(0.254)$ & $(0.134)$ & $(0.180)$ & $(0.898)$ \\
\hline \multirow[t]{2}{*}{ Dependency ratio } & $2.29 * * *$ & $0.63 * * *$ & $0.56^{* * *}$ & $0.54 * * *$ \\
\hline & $(0.445)$ & $(0.101)$ & $(0.093)$ & $(0.103)$ \\
\hline \multirow[t]{2}{*}{ Household size } & $0.70 * * *$ & $1.22 * * *$ & $1.38 * * *$ & $1.36 * * *$ \\
\hline & $(0.034)$ & $(0.037)$ & $(0.045)$ & $(0.051)$ \\
\hline \multirow[t]{2}{*}{ Annual cropland (log) } & $0.65^{* * *}$ & $0.83 * * *$ & $0.47 * * *$ & $0.54 * * *$ \\
\hline & $(0.027)$ & $(0.025)$ & $(0.016)$ & $(0.022)$ \\
\hline \multirow{2}{*}{ Perennial cropland $(\log )$} & $0.63 * * *$ & $0.83 * * *$ & $0.52 * * *$ & 0.60 *** \\
\hline & $(0.032)$ & $(0.023)$ & $(0.021)$ & $(0.026)$ \\
\hline Residential land and & $0.78 * * *$ & 1.01 & $0.75^{* * *}$ & $0.66 * * *$ \\
\hline
\end{tabular}




\begin{tabular}{|c|c|c|c|c|}
\hline gardens $(\log )$ & $(0.056)$ & $(0.053)$ & $(0.043)$ & $(0.045)$ \\
\hline \multicolumn{5}{|l|}{ Commune-level factors } \\
\hline \multirow[t]{2}{*}{ Road access to villages } & $1.61 *$ & 0.95 & $1.59 * *$ & $1.54^{*}$ \\
\hline & $(0.392)$ & $(0.150)$ & $(0.314)$ & $(0.381)$ \\
\hline \multirow{2}{*}{$\begin{array}{l}\text { Non-farming job } \\
\text { opportunities }\end{array}$} & 1.27 & $1.45^{* * *}$ & $1.97 * * *$ & $1.77 * * *$ \\
\hline & $(0.212)$ & $(0.177)$ & $(0.272)$ & $(0.286)$ \\
\hline \multirow[t]{2}{*}{ Irrigation facilities } & 0.81 & $0.78 * * *$ & $0.67 * * *$ & 0.94 \\
\hline & $(0.106)$ & $(0.074)$ & $(0.073)$ & $(0.121)$ \\
\hline \multirow[t]{2}{*}{ Coastal area } & 0.87 & $0.46^{* * * *}$ & $0.42 * * *$ & $0.29 * * *$ \\
\hline & $(0.348)$ & $(0.131)$ & $(0.129)$ & $(0.107)$ \\
\hline \multirow[t]{2}{*}{ Inland delta } & 1.19 & 0.93 & 1.04 & 0.85 \\
\hline & $(0.325)$ & $(0.170)$ & $(0.214)$ & $(0.210)$ \\
\hline \multirow[t]{2}{*}{ Hills/midlands } & 1.13 & $1.78^{* *}$ & $1.95^{* *}$ & 1.16 \\
\hline & $(0.474)$ & $(0.513)$ & $(0.599)$ & $(0.409)$ \\
\hline \multirow[t]{2}{*}{ Low mountains } & 1.21 & $1.47 * *$ & 1.01 & 0.82 \\
\hline & $(0.322)$ & $(0.239)$ & $(0.206)$ & $(0.204)$ \\
\hline \multirow[t]{2}{*}{ Constant } & $0.28 * *$ & 0.64 & 1.07 & $0.18 * * *$ \\
\hline & $(0.155)$ & $(0.218)$ & $(0.399)$ & $(0.081)$ \\
\hline Pseudo R2 & \multicolumn{4}{|c|}{0.20} \\
\hline Observations & \multicolumn{4}{|c|}{6,559} \\
\hline
\end{tabular}

Note: Estimates are adjusted for sampling weights and clustered at the commune level. Robust standard errors in parentheses ${ }^{\star \star *} p<0.01,{ }^{* \star} p<0.05,{ }^{*} p<0.1$.

Farm work livelihoods are the base or reference group. The area of all land types was divided by 100 and transformed into the natural logarithm. The omitted categories in the dummy variable analyses are female, not married, ethnic minorities, no transport infrastructure accessing the villages, other nonfarming opportunities, no irrigation work, high mountains, the Northwest region.

Source: authors' calculation from the VHLSS 2014.

The research showed that the education of household heads is positively correlated with the choice of wage-earning or non-farming livelihoods. For instance, given a one-year increase in a household head's formal schooling, the relative probability of choosing non-farming livelihood increases by $14 \%$ and the relative probability of choosing wage-earning work increases by $13 \%$. The research finding is in line with that of several studies in rural Vietnam and other developing countries, for example that of Tran (2015), who found that education increases the likelihood of households seeking high return livelihoods. The finding supports the argument made by Reardon et al. (2000) that better education may shift households away from farming and the most lucrative nonfarm opportunities often require higher levels of education.

Unsurprisingly, the current research finds that owning farmland is negatively associated with the likelihood of choosing wage-earning or non-farming livelihoods, suggesting that the possession of more farmland does not encourage households to specialise in non-farming activities. This result supports previous findings in several developing societies which show that there is a negative relationship between farmland holdings and engaging in non-farming work (Carletto et al., 2007). In the current study, the negative association between the ownership of farmland and the choice of the two most lucrative strategies (nonfarming and wage-earning livelihoods) suggests that owning farmland is not a 
potential barrier to adopting high return strategies in rural Vietnam. A similar trend can be seen in several developing countries, where households lacking available farmland tend to diversify their livelihoods towards the non-farming sector, in this way inducing rural households to pursue these means of improving their household income (Winters et al., 2009).

Regarding the role of commune-level factors in livelihood choice, the authors found that, keeping all other variables constant, in communes that are accessible by road and where non-farming opportunities are available, households are more likely to adopt a strategy based on wage-earning work. For example, the relative probability ratio of choosing a non-farming livelihood (compared to a farming one) would be 1.59 times higher for those living in communes accessible by land. Similarly, the relative probability ratio of adopting a wage-earning livelihood (compared to a farming one) would be 1.77 times higher for those living in communes where there are non-farming job opportunities. Arriving at similar findings for the Northwest region of Vietnam, Tran (2015) reported that households living in communes accessible by land and where non-farming job opportunities were available were more likely to take up non-farming activities.

\section{Conclusion and policy implications}

The current study provides a detailed picture of household livelihood strategies in rural Vietnam using cluster analysis techniques. Five livelihood strategies were identified at the household level. The results from Bonferroni pairwise tests indicate that whereas wage-paying and non-farming livelihoods provide the highest returns, farming and farming and wage-earning livelihoods are the least remunerative. The econometric evidence shows a negative link between land endowment and the choice of non-farming or wage-earning livelihoods. This suggests that households owning less farmland are more likely to pursue high return livelihoods (wage-earning or non-farming livelihoods). Thus, landlessness is not a potential barrier barring households from choosing remunerative strategies.

Overall, the research findings suggest that on the one hand, land-limited households might be pushed into the rural non-farming sector to compensate for the adverse context of land shortage, and on the other hand, they may be drawn into non-farming activities because of the high returns they offer. The findings support the arguments of several studies (e.g. Bouahom, Douangsavanh \& Rigg, 2004; Davis, 2006; Deshingkar, 2005; Koczberski \& Curry, 2005; Rigg, 2006) that in certain situations, the rising numbers of the landless or the drop in the availability of land should be seen as a positive trend because they create opportunities for diversifying livelihood strategies and reducing dependence on land. In addition, the research indicates that households with better education are more likely to pursue lucrative non-farming activities, such as wage-earning or other non-farming work. This finding implies that land is no longer so influential in shaping rural livelihoods and its role has been gradually taken over 
by other factors, such as education and skills. For this reason, a land distribution policy should not be regarded as the primary approach to rural poverty eradication in Vietnam.

The study also finds that other commune characteristics play an essential role in fostering the pursuit of high return livelihoods. Controlling for other factors, a commune where local enterprises or trade villages are available offers households residing in that commune a better chance of choosing wage-earning or nonfarm work livelihoods. A commune that has an accessible transport infrastructure increases the likelihood that its households will choose non-farming or wage-earning livelihoods. A policy implication here is that by improving local infrastructure (e.g. road access to communes) and expanding local enterprises or trade villages, local governments can create a favourable context for local households to change or diversify their livelihoods towards more productive activities.

\section{References}

Anderson, D.R., Sweeney, D.J., Williams, T.A., Camm, J.D. and Cochran, J.J. (2016), Statistics for business E economics, Nelson Education.

Ansoms, A. (2008), "Rural poverty and livelihood profiles in post-genocide Rwanda" (Discussion Paper), Institute of Development Policy and Management, University of Antwerp, 12 May 2018, https://cutt.ly/3eUewTV.

Bouahom, B., Douangsavanh, L. and Rigg, J. (2004), "Building sustainable livelihoods in Laos: Untangling farm from non-farm, progress from distress", Geoforum, vol. 35, no. 5, p. 607-619.

Brown, D.R., Stephens, E.C., Ouma, J.O., Murithi, F.M. and Barrett, C.B. (2006), "Livelihood strategies in the rural Kenyan highlands", African Journal of Agricultural and Resource Economics, vol. 1, no. 1, p. 21-35.

Carletto, G., Covarrubias, K., Davis, B., Krausova, M., Stamoulis, K., Winters, P., and Zezza, A. (2007), "Rural income generating activities in developing countries: Re-assessing the evidence", Electronic Journal of Agricultural and Development Economics, vol. 4, no. 1, p. 146-193.

Coudouel, A., Hentschel, J.S., and Wodon, Q.T. (2002), "Poverty measurement and analysis" in J. Klugman (ed.), A Sourcebook for poverty reduction strategies, vol. 1, p. 27-74, World Bank, Washington, D.C.

Davis, J.R. (2006), "Rural non-farm livelihoods in transition economies: Emerging issues and policies", Electronic Journal of Agricultural and Development Economics, vol. 3, no. 2, p. 180-224.

Deaton, A. (1997), The analysis of household surveys: A microeconometric approach to development policy, World Bank Publications.

Deshingkar, P. (2005), "Maximizing the benefits of internal migration for development", Paper presented at the Regional Conference on Migration and Development in Asia, Lanzhou, China, 12 March 2018, https://cutt.ly/CeUeecY. 
Ellis, F. (2000), Rural livelihoods and diversity in developing countries, New York, Oxford University Press.

Greene, W.H. (2003), Econometric analysis (5th ed.), Pearson Education, Upper Saddle River, NJ.

General Statistical Office (2015), Results of Vietnam Household Living Standard Survey 2014, General Statistical Office, Hanoi, Vietnam.

Hair, J.F., Anderson, R.E., Tatham, R.L. and William, C. (1998), Multivariate data analysis, NJ: Prentice Hall, Upper Saddle River.

Halpin, B. (2016), Duda-Hart: Stata module to calculate and graph Duda-Hart cluster stopping indices from distance matrix. Statistical Software Components S458195, Boston, Boston College Department of Economics.

Jansen, H., Pender, J., Damon, A., Wielemaker, W. and Schipper, R. (2006), "Policies for sustainable development in the hillside areas of Honduras: A quantitative livelihoods approach", Agricultural Economics, vol. 34, no. 2, p. 141153.

Koczberski, G. and Curry, G. (2005), "Making a living: Land pressures and changing livelihood strategies among oil palm settlers in Papua New Guinea", Agricultural Systems, vol. 85, no. 3, p. 324-339.

Nguyen, C.V. and Tran, A.N. (2013), "The role of crop land during economic development: Evidence from rural Vietnam", European Review of Agricultural Economics, vol. 41, no. 4, p. 561-582.

Nielsen, Ø.J., Rayamajhi, S., Uberhuaga, P., Meilby, H. and Smith-Hall, C. (2013), "Quantifying rural livelihood strategies in developing countries using an activity choice approach", Agricultural Economics, vol. 44, no. 1, p. 57-71.

Pham, T.H., Bui, A.T. and Dao, L.T. (2010), "Is nonfarm diversification a way out of poverty for rural households? Evidence from Vietnam in 1993-2006", PMMA Working Paper 2010-17, Social Science Research Network, 20 May 2018, https://cutt.ly/seUerpY.

Punj, G. and Stewart, D.W. (1983), "Cluster analysis in marketing research: Review and suggestions for application", Journal of Marketing Research, vol. 20, no. 2, p. 134-148.

Ravallion, M. and Van de Walle, D. (2008), "Does rising landlessness signal success or failure for Vietnam's agrarian transition?", Journal of Development Economics, vol. 87, no. 2, p. 191-209.

Reardon, T., Taylor, J.E., Stamoulis, K., Lanjouw, P. and Balisacan, A. (2000), "Effects of nonfarm employment on rural income inequality in developing countries: An investment perspective", Journal of Agricultural Economics, vol. 51, no. 2, p. 266-288.

Rigg, J. (2006). Land, farming, livelihoods, and poverty: Rethinking the links in the rural South. World Development, 34(1), 180-202.

Tran, T.Q. (2015), "Nonfarm employment and household income among ethnic minorities in Vietnam", Economic Research - Ekonomska Istraživanja, vol. 28, no. 1, p. 703-716. 
Tran, T.Q., Lim, S., Cameron, M. and Vu, H.V. (2014), "Farmland loss, nonfarm diversification and inequality among households in Hanoi's peri-urban areas, Vietnam", International Development Planning Review, vol. 36, no. 3, p. 357-379.

Tran, T.Q., Lim, S., Cameron, M.P. and Van, H.V. (2014), "Farmland loss and livelihood outcomes: A microeconometric analysis of household surveys in Vietnam", Journal of the Asia Pacific Economy, vol. 19, no. 3, p. 423-444.

Tran, T.Q., Nguyen, S.H., Vu, H.V. and Nguyen, V.Q. (2015), "A note on poverty among ethnic minorities in the Northwest region of Vietnam", Post-Communist Economies, vol. 27, no. 2, p. 268-281.

Tran, T.Q., Tran, A.L., Pham, T.M. and Vu, H.V. (2018), "Local governance and occupational choice among young people: First evidence from Vietnam", Children and Youth Services Review, vol. 86, no. 2, p. 21-31.

Van den Berg, M. (2010), "Household income strategies and natural disasters: Dynamic livelihoods in rural Nicaragua", Ecological Economics, vol. 69, no. 3, p. 592-602.

World Bank (2011), Vietnam development report 2011: Natural resources management. Washington, DC: World Bank, 23 May 2017, https://cutt.ly/aeUetwq.

World Bank (2016), Arable land (hectares per person), Washington, DC: World Bank, 21 May 2018, https://cutt.ly/9eUeyvN.

Winters, P., Davis, B., Carletto, G., Covarrubias, K., Quiñones, E.J., Zezza, A. and Stamoulis, K. (2009), "Assets, activities and rural income generation: Evidence from a multicountry analysis", World Development, vol. 37, no. 9, p. 1435-1452. 